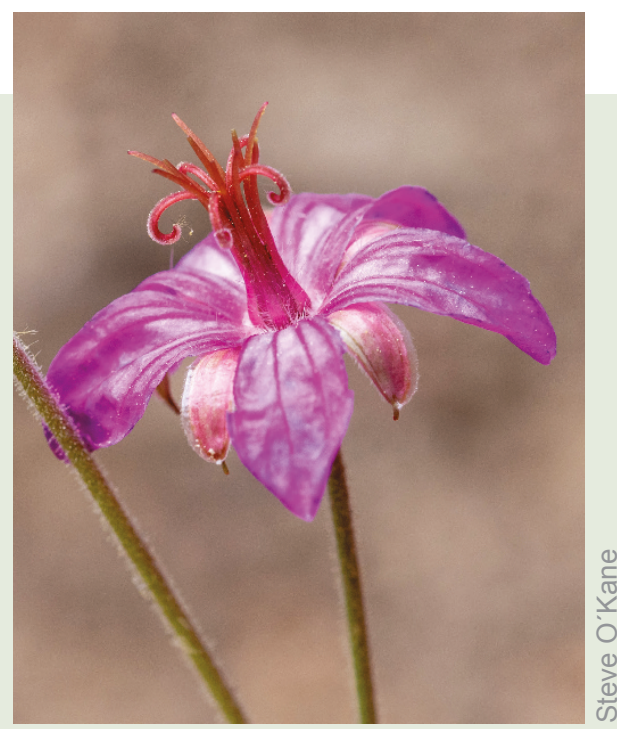

Syn.: G. atropurpureum A.Heller, G. cowenii Rydb., G. eremophilum Wooton \& Standl., G. fremontii Torr. ex A.Gray, G. marginale Rydb., G. parryi A.Heller, G. pattersonii Rydb., G. thermale Rydb., G. toquimense N.H.Holmgren \& A.H.Holmgren

Description: Perennial herbs, 30-50 cm tall, cespitose, pubescent, stems erect, often divaricately branched, leaves palmatipartite to -sect, margins incised, or lobed, flowers light pink to purple, 3-4 cm across, in axillary cymes.
Distribution:W North America (N Mexico, Arizona, Colorado, Nevada, New Mexico, Texas, Utah, Wyoming).

Habitat: Damp understory of coniferous forests, canyons, along streams.

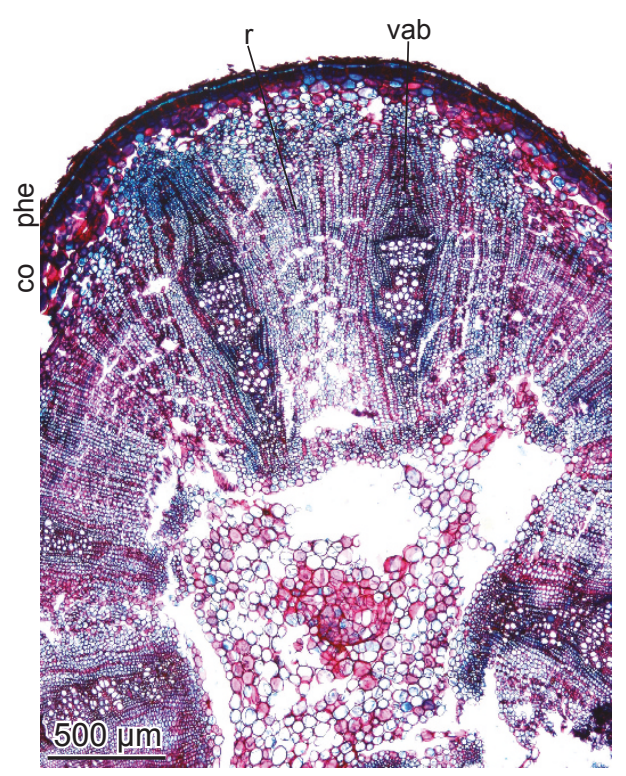

Rhizome with a diameter of $7 \mathrm{~mm}$. Xylem to bark ratio I: I. Rings distinct. Maximal 4 rings. Mean ring width $0.3 \mathrm{~mm}$. Analyzed: I individual.

Xylem

Transverse section

Semi-ring-porous. Ring boundaries marked by a difference in latewood (10-20 $\mu \mathrm{m})$ and earlywood (35-45 $\mu \mathrm{m})$ vessel diameters. Vessel outline angular. Vessels lignified, solitary and in small groups. Fibers thinto thick-walled. Parenchyma paratracheal. Crystals absent. Shape of vascular bundles remaining over several years.

\section{Tangential section}

Rays absent within vascular bundles. Rays >10-seriate between vascular bundles, confluent with the axial tissue.

\section{Radial section}

Perforation plates simple. Intervessel pits round. Vessel length 60-100 $\mu \mathrm{m}$.

Bark

Sieve elements and parenchyma uniform. Sclerenchyma absent. Phellem cells rectangular, in tangential rows.

Pith

Polygonal.

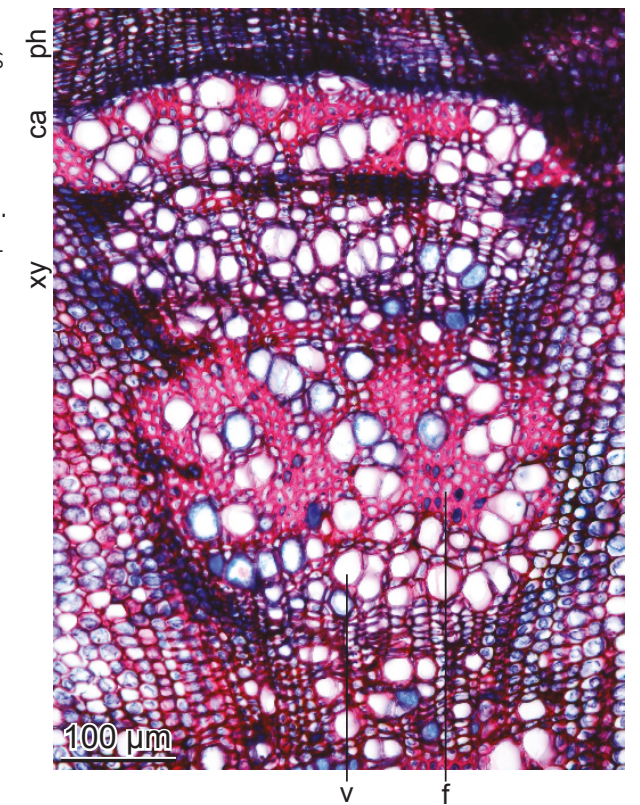

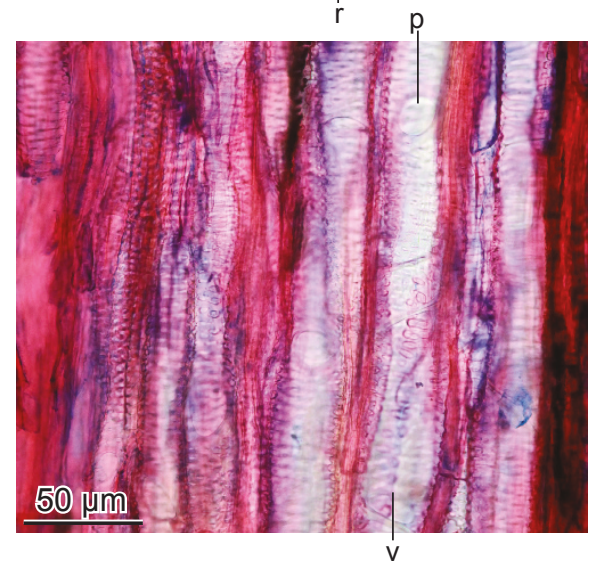

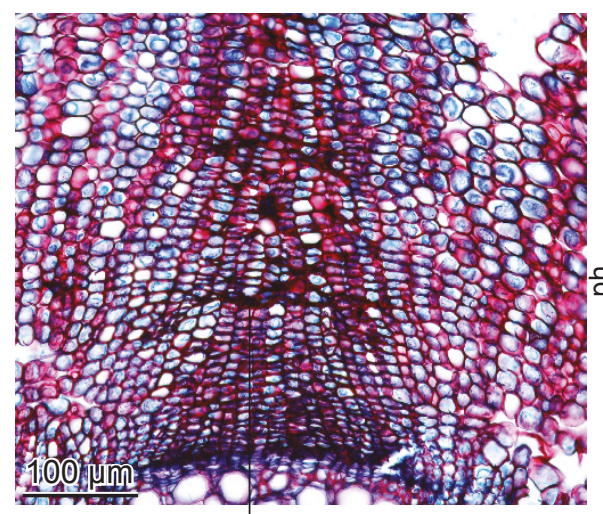

Features according to IAWA and Crivellaro and Schweingruber 2015

Xylem I - 4- 9 - 12 - 13 - 22 - 40.2 - 50.2 - 52.3 - 61 - 70 - 79.1 - 99 - 99.1 - 100.1 - 100.2 - 105 